\title{
Article
}

\section{A contribution to the mineralogy of Sicily, Italy - Kintoreite from the Tripi mine, Peloritani Mountains: occurrence and crystal structure}

\author{
Daniela Mauro ${ }^{1 \star}$ (D), Cristian Biagioni ${ }^{2}$ (D) and Federica Zaccarini ${ }^{3}$ \\ ${ }^{1}$ Museo di Storia Naturale, Università di Pisa, Via Roma 79, I-56011 Calci (PI), Italy; ${ }^{2}$ Dipartimento di Scienze della Terra, Università di Pisa, Via Santa Maria 53 , \\ I-56126 Pisa, Italy; and ${ }^{3}$ Department of Applied Geological Sciences and Geophysics, University of Leoben, Peter Tunner Str. 5, A-8700 Leoben, Austria
}

\begin{abstract}
A new occurrence of kintoreite, ideally $\mathrm{PbFe}_{3}\left(\mathrm{PO}_{4}\right)\left(\mathrm{PO}_{3} \mathrm{OH}\right)(\mathrm{OH})_{6}$, is described from the Tripi mine, Alì, Peloritani Mountains, northeastern Sicily, Italy. Kintoreite occurs as yellow equant crystals, up to $0.05 \mathrm{~mm}$ in size, on quartz, associated with another alunite-supergroup mineral currently under study. The studied grains of kintoreite are chemically zoned, showing the occurrence of two distinct domains. Electron microprobe analyses gave (in wt.\%): $\mathrm{SO}_{3}$ 5.47(27), $\mathrm{P}_{2} \mathrm{O}_{5} 17.55(14), \mathrm{Al}_{2} \mathrm{O}_{3} 7.81(35), \mathrm{Fe}_{2} \mathrm{O}_{3} 23.81(44)$, $\mathrm{PbO}$ 35.11(41), $\mathrm{H}_{2} \mathrm{O}_{\text {calc }}$ 9.93, total 99.68 (darker domains) and $\mathrm{SO}_{3} 6.03(5), \mathrm{P}_{2} \mathrm{O}_{5}$ 16.66(23), $\mathrm{Al}_{2} \mathrm{O}_{3} 4.22(2), \mathrm{Fe}_{2} \mathrm{O}_{3} 27.31(6), \mathrm{PbO}^{2}$ $33.78(22), \mathrm{H}_{2} \mathrm{O}_{\text {calc }} 10.25$, total 98.25 (brighter domains). On the basis of $14 \mathrm{O}$ atoms per formula unit $($ apfu) and $(\mathrm{P}+\mathrm{S})=2$ apfu, the darker and brighter domains have chemical formula $\mathrm{Pb}_{1.00}\left(\mathrm{Fe}_{1.89}^{3+} \mathrm{Al}_{0.97}\right)_{\Sigma 2.86}\left[\mathrm{P}_{1.57} \mathrm{~S}_{0.43} \mathrm{O}_{7.43}(\mathrm{OH})_{0.57}\right]\left[(\mathrm{OH})_{5.58}\left(\mathrm{H}_{2} \mathrm{O}\right)_{0.42}\right]_{\Sigma 6.00}$ and $\mathrm{Pb}_{0.98}\left(\mathrm{Fe}_{2.21}^{3+} \mathrm{Al}_{0.53}\right)_{\Sigma 2.74}\left[\mathrm{P}_{1.51} \mathrm{~S}_{0.49} \mathrm{O}_{7.49}(\mathrm{OH})_{0.51}\right]\left[(\mathrm{OH})_{5.18}\left(\mathrm{H}_{2} \mathrm{O}\right)_{0.82}\right]_{\Sigma 6.00}$, respectively. Single-crystal X-ray diffraction was performed on a grain extracted from the same sample. Unit-cell parameters are $a=7.2191(10), c=16.834(3) \AA, V=759.8(3) \AA^{3}$ and $Z=3$; space group $R \overline{3} \mathrm{~m}$. The crystal structure was refined on the basis of 226 unique reflections with $F_{\mathrm{o}}>4 \sigma\left(F_{\mathrm{o}}\right)$ and 31 least-square parameters to $R_{1}=0.0415$. Kintoreite is isotypic with other alunite-supergroup minerals. Micro-Raman spectroscopy suggests the possible occurrence of $\mathrm{H}_{2} \mathrm{O}$ groups, supporting the possible protonation of $(\mathrm{OH})$ groups as a charge-balance mechanism in this mineral. Kintoreite may play an environmental role in the Alì area, where previous authors detected high concentrations of potentially toxic elements in soils.
\end{abstract}

Keywords: kintoreite, phosphate, alunite supergroup, crystal structure, hydrogen bonds, Peloritani Mountains, Sicily, Italy

(Received 6 August 2021; accepted 9 November 2021; Accepted Manuscript published online: 17 November 2021; Associate Editor: David Hibbs)

\section{Introduction}

Several polymetallic ore deposits were exploited in the Peloritani Mountains, northeastern Sicily, Italy, where small $\mathrm{Pb}-\mathrm{Zn}-\mathrm{Fe}-$ $\mathrm{As}-\mathrm{Sb}-\mathrm{Cu}-\mathrm{Ag}-\mathrm{W}-(\mathrm{Au})$ ore bodies are hosted within tectonic slices affected by both Variscan and Alpine tectono-metamorphic events. Previous authors focused their attention mainly on primary ore minerals (e.g. Saccà et al., 2015, and references therein), whereas little is known about secondary phases occurring in these mineralisations. Some oxides (cervantite, goethite and stibiconite), carbonates (azurite, hydrozincite, malachite and smithsonite), sulfates (anglesite), phosphates (pyromorphite) and arsenates (annabergite, erythrite, scorodite and symplesite) have been reported (Seguenza, 1856; La Valle, 1898, 1899; Traina, 1905; Baldanza, 1950; Triscari and Saccà, 1982, 1984;

${ }^{*}$ Author for correspondence: Daniela Mauro, Email: daniela.mauro@unipi.it This paper is part of a thematic set that honours the contributions of Peter Williams Cite this article: Mauro D., Biagioni C. and Zaccarini F. (2022) A contribution to the mineralogy of Sicily, Italy - Kintoreite from the Tripi mine, Peloritani Mountains: occurrence and crystal structure. Mineralogical Magazine 86, 548-556. https://doi.org/10.1180/ mgm.2021.85
Triscari, 1985; Saccà et al., 2007). However, the geochemistry of the ore bodies suggests the possible existence of other secondary compounds. Their study is not a trivial exercise, because they could play an important role in controlling the geochemical behaviour of several potentially toxic elements (PTE).

De Vivo et al. (1993) pointed out the presence of anomalies of $\mathrm{As}, \mathrm{Hg}, \mathrm{Sb}, \mathrm{Zn}$ and $\mathrm{Pb}$ in stream sediments from the Peloritani Mountains. Cosenza et al. (2015) investigated the soil geochemistry in this area, reporting high contents of PTE such as As, Zn, Sb and $\mathrm{Pb}$. One of the two anomalous areas found in this region is located between Fiumedinisi, Budali and Ali, and $\mathrm{Pb}$ isotopes indicate a geogenic contribution to this contamination, related to the weathering of ore deposits and mine wastes in the area studied.

In the framework of a survey of the mineralogy of the Peloritani Mountains, a sample of galena-bearing quartz vein was sampled from the adit of one of the tunnels belonging to the abandoned Tripi mine, Alì, Messina Province. The observation of this sample under the binocular microscope revealed the occurrence of alunitesupergroup minerals encrusting thin fissures in the quartz vein. One of them formed yellow equant grains, whose chemical composition indicated its classification as kintoreite, a relatively

(C) The Author(s), 2021. Published by Cambridge University Press on behalf of The Mineralogical Society of Great Britain and Ireland. This is an Open Access article, distributed under the terms of the Creative Commons Attribution licence (http://creativecommons.org/licenses/by/4.0/), which permits unrestricted re-use, distribution and reproduction, provided the original article is properly cited. 
uncommon phase first described by Pring et al. (1995) from Broken Hill, New South Wales, Australia.

There are several reasons for characterising this new occurrence of kintoreite. From an environmental perspective, this phase, whose origin is related to the weathering of primary ores, could be a potential host for the $\mathrm{Pb}$ anomaly observed in soils in the Alì area (Cosenza et al., 2015), in agreement with previous studies showing the presence of nanoparticles of kintoreite in soils (e.g. Schindler and Hochella, 2017). Moreover, the finding of kintoreite from the Peloritani Mountains is the third Italian occurrence of this mineral, following the identification reported by Albertini (2014) from the Monte Falò mine, Piedmont, and by Guastoni et al. (2018) from the nearby locality of Chiotta Strivera, Piedmont. Only few data are reported for these occurrences and no crystal-chemical characterisation was performed. Finally, kintoreite from the Tripi mine is enriched in $\mathrm{Al}$ and $\mathrm{S}$ and consequently its full description can provide interesting insights on the crystal chemistry of alunite-supergroup minerals.

\section{Geological background}

The Peloritani Mountains represent the southernmost portion of the Calabria-Peloritani Arc, an arc-like structure that connects the Apennines with the Maghrebian Chain. It is delimited by the Pollino line, in the north, and the Taormina line, in the south (Messina et al., 2004, and references therein). This mountain belt is formed by the stacking of several tectonic units. Ore bodies are hosted mainly in the Mandanici Unit, a tectonic slice formed by low- to medium-grade metamorphic rocks affected by the Variscan orogeny; the Alpine event gave rise to cataclastic-to-mylonitic processes (Ferla and Meli, 2007; Carbone et al., 2007, and references therein). The actual genesis and evolution of the ore deposits of the Peloritani Mountains have been debated by several authors (e.g. Ferla, 1982/1983; Ferla and Omenetto, 2000; Saccà et al., 2003).

Among the most important mining sites, the Tripi mine $\left(38^{\circ} 00^{\prime} 50^{\prime \prime} \mathrm{N} ; 5^{\circ} 24^{\prime} 27^{\prime \prime} \mathrm{E}\right)$ is located some hundred metres SSW of the small hamlet of Alì, Messina Province, Sicily. It exploited a stratabound fine-banded ore, composed mainly of sphalerite and Ag-bearing galena, with rare pyrite and trace amounts of chalcopyrite, arsenopyrite, pyrrhotite and covellite; quartz and fluorite are gangue minerals (Saccà et al., 2007). Secondary products are smithsonite, gypsum, hydrozincite, 'limonite' and malachite (Saccà et al., 2007).

\section{Experimental}

\section{Specimen studied}

Kintoreite occurs as yellow equant crystals, up to $0.05 \mathrm{~mm}$ in size, on quartz, associated with another alunite-supergroup mineral currently under study (Fig. 1a). The sample studied is deposited in the mineralogical collection of the Museo di Storia Naturale of the Università di Pisa, under the catalogue number 19928.

\section{Chemical analysis}

Quantitative chemical analyses were perfomed at the 'Eugen F. Stumpfl' laboratory, University of Leoben (Austria) using a Superprobe JEOL JXA 8200 electron microprobe (WDS mode, accelerating voltage $=20 \mathrm{kV}$, beam current $=10 \mathrm{nA}$ and beam size $=1 \mu \mathrm{m})$. The following standards (element, emission line) were used: crocoite $(\mathrm{Pb} K \alpha)$, magnetite $(\mathrm{Fe} K \alpha)$, apatite $(\mathrm{P} K \alpha)$,
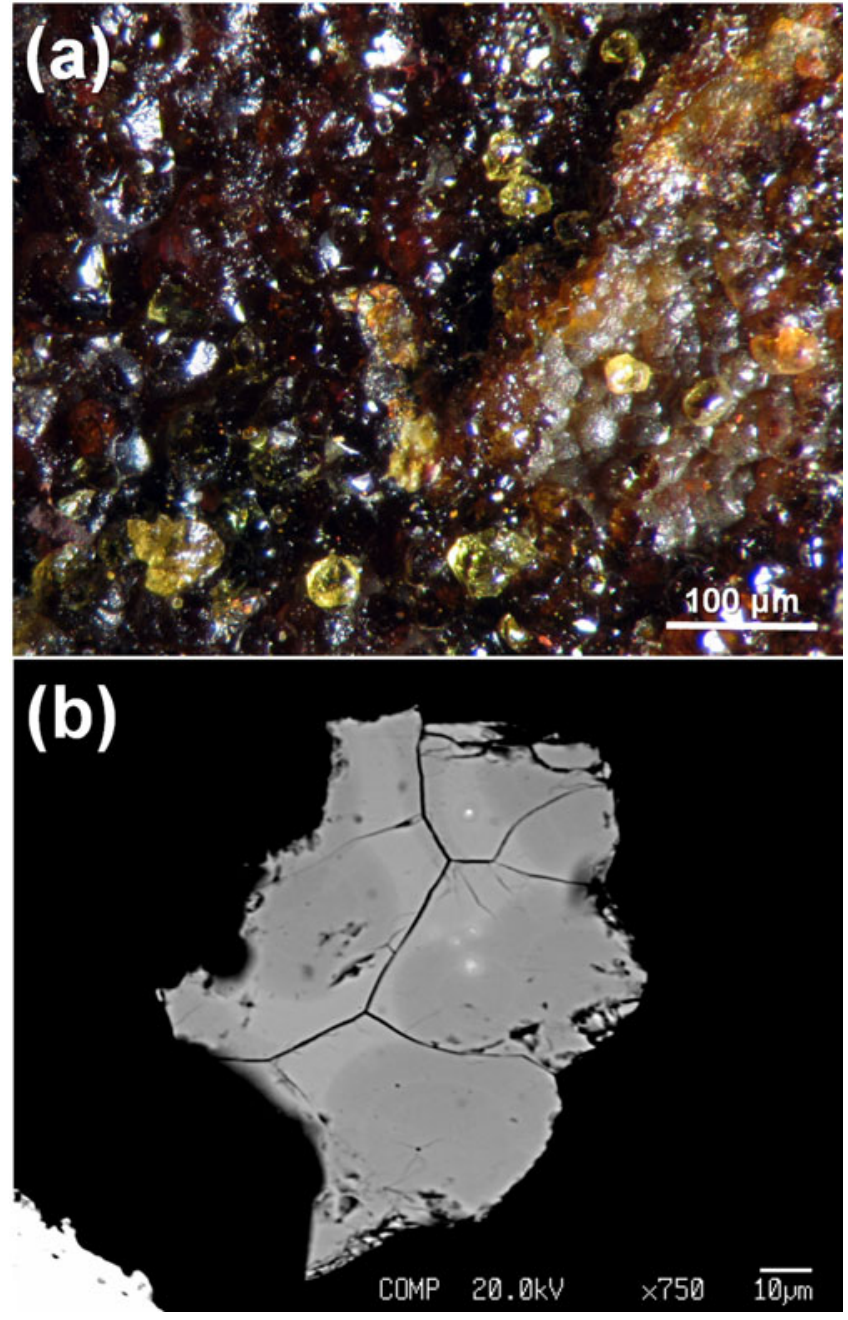

Fig. 1. Kintoreite from the Tripi mine, Alì, Messina Province, Sicily [Collection of the Museo di Storia Naturale, Università di Pisa; catalogue number 19928]. (a) Yellow equant crystals associated with another member of the alunite supergroup, still undetermined, brownish in colour. (b) Back-scattered electron image showing chemical inhomogeneity of kintoreite, with bright (Fe-rich) and dark (Al-rich) domains.

corundum $(\mathrm{Al} K \alpha)$ and anhydrite $(\mathrm{S} K \alpha)$. Other elements $(\mathrm{K}, \mathrm{Sr}$, $\mathrm{Ba}$ and As) were sought but were below the detection limit. The $Z A F$ routine was applied for the correction of the recorded raw data. Counting times were $15 \mathrm{~s}$ for peak and $5 \mathrm{~s}$ for backgrounds. Table 1 gives chemical data.

\section{Micro-Raman spectroscopy}

Micro-Raman spectra were collected using a Horiba Jobin-Yvon XploRA Plus apparatus, equipped with a motorised $x-y$ stage and an Olympus BX41 microscope with a 50× objective (Dipartimento di Scienze della Terra, Università di Pisa). Raman spectra were excited using the $532 \mathrm{~nm}$ line of a solid-state laser, attenuated to $25 \%$ (i.e. $6.25 \mathrm{~mW}$ ) in order to avoid any potential sample damage. The minimum lateral and depth resolution was set to a few $\mu \mathrm{m}$. The system was calibrated using the $520.6 \mathrm{~cm}^{-1}$ Raman band of silicon before each experimental session. Spectra were collected through multiple acquisitions (3) with variable counting times, ranging from 30 to $60 \mathrm{~s}$. Back-scattered radiation was analysed with a $1200 \mathrm{gr} / \mathrm{mm}$ grating monochromator. Raman spectra were processed using Fityk 
(Wojdyr, 2010), subtracting the background and fitting the spectra to theoretical peak shapes using Voigt functions. Experimental precision can be estimated at $\pm 2 \mathrm{~cm}^{-1}$.

\section{$X$-ray crystallography}

Single-crystal X-ray diffraction data were collected at the Dipartimento di Scienze della Terra, Università di Pisa, Italy, using a Bruker Apex II diffractometer operating at $50 \mathrm{kV}$ and $30 \mathrm{~mA}$ and equipped with an air-cooled Photon II CCD detector. Graphite-monochromatised $\mathrm{MoK} \alpha$ radiation was used. The detector-to-crystal working distance was set to $50 \mathrm{~mm}$. Intensity data were integrated and corrected for Lorentz, polarisation, background effects and absorption using the APEX3 software package (Bruker AXS Inc., 2016). Crystal structure refinement was performed using Shelxl-2018 (Sheldrick, 2015) starting from the atomic coordinates given by Kharisun et al. (1997) for kintoreite. Neutral scattering curves were taken from the International Tables for Crystallography (Wilson, 1992). The following scattering curves were used: $\mathrm{Pb}$ at the $\mathrm{Pb}$ site, $\mathrm{Fe}$ at the $\mathrm{Fe}$ site, $\mathrm{P}$ at the $P$ site, and $\mathrm{O}$ at the $\mathrm{O}(1)-\mathrm{O}(3)$ sites. After several cycles of isotropic refinement, the $R_{1}$ factor converged to 0.0674 , thus confirming the correctness of the structural model. Taking into account chemical data, the site occupancy at the $F e$ site was refined using the scattering curves of $\mathrm{Fe} v s$. Al, improving the quality of refinement to $R_{1}=0.0447$. Owing to the similar scattering factors for $\mathrm{P}(Z=15)$ and $\mathrm{S}(Z=16)$, only the scattering curve of the former was used. Introducing the anisotropic displacement parameters for all atoms decreased the $R_{1}$ to 0.0376 . However, $\mathrm{Pb}$ was negatively defined and consequently the final model was refined using anisotropic displacement parameters for all atoms but $\mathrm{Pb}$. A maximum residual, interpreted as an $\mathrm{H}$ atom bonded to $\mathrm{O}(3)$, was located in the difference-Fourier map and a restraint on the $\mathrm{O}(3)-\mathrm{H}$ bond distance was added. The refinement converged to $R_{1}=0.0415$ for 226 unique reflections with $F_{\mathrm{o}}>4 \sigma$ $\left(F_{\mathrm{o}}\right)$ and 31 least-square parameters. Details of data collection and structure refinement are in Table 2, whereas atomic coordinates and displacement parameters are shown in Table 3. Bond distances and bond-valence sums, calculated according to the bond parameters of Gagné and Hawthorne (2015), are given in Tables 4 and 5, respectively. The crystallographic information file has been deposited with the Principal Editor of Mineralogical Magazine and is available as Supplementary material (see below).

\section{Results and discussion}

\section{Chemical data}

The back-scattered electron image of the grain studied revealed a compositional inhomogeneity (Fig. 1b), with dark and bright domains, related to different $\mathrm{Fe} / \mathrm{Al}$ atomic ratios. Electron microprobe data were recalculated on the basis of $14 \mathrm{O}$ atoms per formula unit (apfu), calculating the amount of $\mathrm{H}_{2} \mathrm{O}$ in order to constrain the sum of $(\mathrm{P}+\mathrm{S})$ to 2 apfu. The darker domains have the chemical formula $\mathrm{Pb}_{1.00}\left(\mathrm{Fe}_{1.89}^{3+} \mathrm{Al}_{0.97}\right)_{\Sigma 2.86}$ $\left[\mathrm{P}_{1.57} \mathrm{~S}_{0.43} \mathrm{O}_{7.43}(\mathrm{OH})_{0.57}\right]\left[(\mathrm{OH})_{5.58}\left(\mathrm{H}_{2} \mathrm{O}\right)_{0.42}\right]_{\Sigma 6.00}$, whereas the brighter ones correspond to $\mathrm{Pb}_{0.98}\left(\mathrm{Fe}_{2.21}^{3+} \mathrm{Al}_{0.53}\right)_{\Sigma 2.74}$ $\left[\mathrm{P}_{1.51} \mathrm{~S}_{0.49} \mathrm{O}_{7.49}(\mathrm{OH})_{0.51}\right]\left[(\mathrm{OH})_{5.18}\left(\mathrm{H}_{2} \mathrm{O}\right)_{0.82}\right]_{\Sigma 6.00}$.

To the best of our knowledge, the sample from the Tripi mine has the highest $\mathrm{S}$ content among kintoreite occurrences reported in literature. Kharisun et al. (1997) described a
Table 1. Electron microprobe data for kintoreite from the Tripi mine.

\begin{tabular}{|c|c|c|c|c|c|c|}
\hline \multirow[b]{3}{*}{ Oxide } & \multicolumn{3}{|c|}{ Dark domain } & \multicolumn{3}{|c|}{ Bright domain } \\
\hline & \multicolumn{3}{|c|}{$(n=3)$} & \multicolumn{3}{|c|}{$(n=2)$} \\
\hline & wt. $\%$ & range & $\sigma$ & wt. $\%$ & range & $\sigma$ \\
\hline $\mathrm{SO}_{3}$ & 5.47 & $5.18-5.71$ & 0.27 & 6.03 & $5.99-6.06$ & 0.05 \\
\hline $\mathrm{P}_{2} \mathrm{O}_{5}$ & 17.55 & $17.40-17.68$ & 0.14 & 16.66 & $16.50-16.82$ & 0.23 \\
\hline $\mathrm{Al}_{2} \mathrm{O}_{3}$ & 7.81 & $7.57-8.21$ & 0.35 & 4.22 & $4.21-4.23$ & 0.02 \\
\hline $\mathrm{Fe}_{2} \mathrm{O}_{3}$ & 23.81 & $23.31-24.15$ & 0.44 & 27.31 & $27.27-27.36$ & 0.06 \\
\hline $\mathrm{PbO}$ & 35.11 & $34.82-35.58$ & 0.41 & 33.78 & $33.62-33.94$ & 0.22 \\
\hline $\mathrm{H}_{2} \mathrm{O}_{\text {calc }^{*}}$ & 9.93 & & & 10.25 & & \\
\hline Total & 99.68 & & & 98.25 & & \\
\hline
\end{tabular}

$n=$ number of spot analyses. ${ }^{\star}$ Calculated in agreement with structural data. $\sigma=$ estimated standard deviation.

Table 2. Summary of crystal data and parameters describing data collection and refinement for kintoreite from the Tripi mine.

\begin{tabular}{ll}
\hline Crystal data & \\
X-ray formula & $\mathrm{Pb}\left(\mathrm{Fe}_{1.86}^{3+} \mathrm{Al}_{1.14}\right)\left[\mathrm{PO}_{3.5}(\mathrm{OH})_{0.5}\right]_{2}(\mathrm{OH})_{6}$ \\
Crystal size $(\mathrm{mm})$ & $0.080 \times 0.080 \times 0.050$ \\
Cell setting, space group & Trigonal, $R \overline{3} \mathrm{~m}$ \\
$a(\AA)$ & $7.2191(10)$ \\
$C(\AA)$ & $16.834(3)$ \\
$V\left(\AA^{3}\right)$ & $759.8(3)$ \\
$Z$ & 3 \\
Data collection and refinement & \\
Radiation, wavelength $(\AA)$ & MoKo, $\lambda=0.71073$ \\
Temperature $(\mathrm{K})$ & $293(2)$ \\
$2 \theta_{\text {max }}\left({ }^{\circ}\right)$ & 54.91 \\
Measured reflections & 1160 \\
Unique reflections & 242 \\
Reflections with $F_{\mathrm{o}}>4 \sigma\left(F_{\mathrm{o}}\right)$ & 226 \\
$R_{\text {int }}$ & 0.0300 \\
$R \sigma$ & 0.0258 \\
Range of $h, k, l$ & $-9 \leq h \leq 9,-9 \leq k \leq 8,-11 \leq l \leq 21$ \\
$R\left[F_{\mathrm{o}}>4 \sigma\left(F_{\mathrm{o}}\right)\right]$ & 0.0415 \\
$R($ all data) & 0.0454 \\
$W R\left(\text { on } F_{\mathrm{o}}^{2}\right)^{1}$ & 0.0985 \\
Goof & 1.226 \\
Number of least-squares parameters & 30 \\
Max. and min. residual peak $\left(e \AA^{-3}\right)$ & $1.21[$ at $0.66 \AA$ from $P b]$ \\
& $-1.14[$ at $1.00 \AA$ from $\mathrm{O}(1)]$ \\
&
\end{tabular}

${ }^{1} W=1 /\left[\sigma^{2}\left(F_{\mathrm{o}}^{2}\right)+(0.0252 P)^{2}+41.9069 P\right]$, where $P=\left(F_{\mathrm{o}}^{2}+2 F_{\mathrm{c}}^{2}\right) / 3$.

kintoreite with a significant As and $\mathrm{S}$ substitution for $\mathrm{P}$, i.e. $0.40 \mathrm{As}$ apfu and $0.30 \mathrm{~S}$ apfu. On the contrary, several findings from Slovakia and the Czech Republic have negligible S contents (Pauliš et al., 2012; Števko et al., 2016; Vrtiška et al., 2019, 2021). The substitution of $\mathrm{Fe}^{3+}$ by $\mathrm{Al}^{3+}$ in the octahedral site agrees with the wide substitution observed between kintoreite and plumbogummite, ideally $\mathrm{PbAl}_{3}\left(\mathrm{PO}_{4}\right)\left(\mathrm{PO}_{3} \mathrm{OH}\right)(\mathrm{OH})_{6}$, by other authors (e.g. Vrtiška et al., 2016).

\section{Micro-Raman spectroscopy}

The Raman spectral features of kintoreite from the Tripi mine are shown in Fig. 2. Between 100 and $1200 \mathrm{~cm}^{-1}$ (Fig. 2a), two regions can be distinguished. The first one, between 900 and $1200 \mathrm{~cm}^{-1}$, is characterised by stretching modes of $\mathrm{P}-\mathrm{O}$ bonds and, probably, of $\mathrm{S}-\mathrm{O}$ bonds. In the second region, between 100 and $650 \mathrm{~cm}^{-1}$, bending modes of $\mathrm{O}-\mathrm{P}-\mathrm{O}$ and $\mathrm{O}-\mathrm{S}-\mathrm{O}$ bonds, as well as $\mathrm{M}-\mathrm{O}$ $(\mathrm{M}=\mathrm{Pb}, \mathrm{Fe}$ and $\mathrm{Al})$ and lattice vibrations occur. Observed 
Table 3. Sites, Wyckoff positions, site occupancy factors (s.o.f.), fractional atom coordinates and isotropic $\left({ }^{\star}\right)$ or equivalent isotropic displacement parameters $\left(\AA^{2}\right)$ for kintoreite from the Tripi mine.

\begin{tabular}{|c|c|c|c|c|c|c|}
\hline Site & Wyckoff position & s.o.f. & $x / a$ & $y / b$ & $z / c$ & $U_{\text {iso/eq }}$ \\
\hline $\mathrm{Pb}$ & $18 h$ & $\mathrm{~Pb}_{0.167}$ & $-0.02567(14)$ & $0.02567(14)$ & $0.0000(7)$ & $0.0187(6)^{\star}$ \\
\hline $\mathrm{Fe}$ & $9 d$ & $\mathrm{Fe}_{0.62(2)} \mathrm{Al}_{0.38(2)}$ & $1 / 2$ & 0 & $1 / 2$ & $0.0092(8)$ \\
\hline$P$ & $6 c$ & $\mathrm{P}_{1.00}$ & 0 & 0 & $0.3098(3)$ & $0.0133(9)$ \\
\hline $\mathrm{O}(1)$ & $6 c$ & $\mathrm{O}_{1.00}$ & 0 & 0 & $0.6005(7)$ & $0.017(3)$ \\
\hline $\mathrm{O}(2)$ & $18 h$ & $\mathrm{O}_{1.00}$ & $0.2186(6)$ & $-0.2186(6)$ & $-0.0555(4)$ & $0.0172(14)$ \\
\hline $\mathrm{O}(3)$ & $18 h$ & $\mathrm{O}_{1.00}$ & $0.1272(6)$ & $-0.1272(6)$ & $0.1334(4)$ & $0.0142(13)$ \\
\hline $\mathrm{H}$ & $18 h$ & $\mathrm{H}_{1.00}$ & $0.198(7)$ & $-0.198(7)$ & $0.110(10)$ & $0.08(6)^{\star}$ \\
\hline
\end{tabular}

Table 4. Selected bond distances $(\AA)$ for kintoreite from the Tripi mine.

\begin{tabular}{llll}
\hline $\mathrm{Pb}-\mathrm{O}(3)$ & $2.579(12)$ & $\mathrm{Fe}-\mathrm{O}(3)$ & $1.968(3) \times 4$ \\
$\mathrm{~Pb}-\mathrm{O}(2)$ & $2.587(8)$ & $\mathrm{Fe}-\mathrm{O}(2)$ & $1.981(7) \times 2$ \\
$\mathrm{~Pb}-\mathrm{O}(3)$ & $2.677(12) \times 2$ & $\mathrm{Fe}-\mathrm{O}>$ & 1.972 \\
& & & \\
$\mathrm{~Pb}-\mathrm{O}(2)$ & $2.751(8) \times 2$ & & \\
$\mathrm{~Pb}-\mathrm{O}(3)$ & $2.860(11) \times 2$ & $P-\mathrm{O}(1)$ & $1.510(12)$ \\
$\mathrm{Pb}-\mathrm{O}(3)$ & $2.949(12)$ & $\mathrm{P}-\mathrm{O}(2)$ & $1.532(7) \times 3$ \\
$\mathrm{~Pb}-\mathrm{O}(2)$ & $3.054(8) \times 2$ & $<\mathrm{P}-\mathrm{O}>$ & 1.526 \\
$\mathrm{~Pb}-\mathrm{O}(2)$ & $3.194(8)$ & & \\
$<\mathrm{Pb}-\mathrm{O}>$ & 2.833 & & \\
\hline
\end{tabular}

Table 5. Weighted bond-valence sums (in valence unit) for kintoreite from the Tripi mine.

\begin{tabular}{|c|c|c|c|c|c|c|}
\hline Site & $\mathrm{Pb}$ & $\mathrm{Fe}$ & $P$ & Eanions & Sanions $^{1}$ & Theor. \\
\hline $\mathrm{O}(1)$ & & & 1.34 & 1.34 & $\begin{array}{l}1.97^{\mathrm{a}} \\
1.25^{\mathrm{b}}\end{array}$ & 2.00 \\
\hline$O(2)$ & $\begin{array}{l}0.28 \\
0.19^{\times 2 \downarrow} \\
0.10^{\times 2 \downarrow} \\
0.07\end{array}$ & $0.47^{\times 2 \downarrow}$ & $1.27^{\times 3 \downarrow}$ & $1.81-2.02$ & $\begin{array}{l}1.81-2.02^{\mathrm{a}} \\
1.90-2.11^{\mathrm{b}}\end{array}$ & 2.00 \\
\hline$O(3)$ & $\begin{array}{l}0.28 \\
0.23^{\times 2 \downarrow} \\
0.15^{\times 2 \downarrow} \\
0.12\end{array}$ & $2 \times \rightarrow 0.49^{\times 4 \downarrow}$ & & $1.10-1.26$ & $\begin{array}{l}0.92-1.08^{\mathrm{a}} \\
1.01-1.17^{\mathrm{b}}\end{array}$ & 1.00 \\
\hline ¿cations & 2.09 & 2.90 & 5.15 & & & \\
\hline Theor. & 2.00 & 3.00 & 5.22 & & & \\
\hline
\end{tabular}

Note: left and right superscripts indicate the number of equivalent bonds involving cations and anions, respectively. The site occupancies $\left(\mathrm{Fe}_{0.68} \mathrm{Al}_{0.32}\right)$ and $\left(\mathrm{P}_{0.78} \mathrm{~S}_{0.22}\right)$ were used for calculating the bond-valence sums at $\mathrm{Fe}$ and $P$ sites. ${ }^{1}$ Corrected for $\mathrm{H}$-bonds. ${ }^{\mathrm{a}} \mathrm{O}(1)$ acting as acceptor of $\mathrm{H}$-bonds. ${ }^{\mathrm{b}} \mathrm{O}(1)$ acting as donor of $\mathrm{H}$-bonds.

bands agree with the general features described by Frost et al. (2006). The interpretation of the weak band at $820 \mathrm{~cm}^{-1}$, attributed to the occurrence of $\left(\mathrm{AsO}_{4}\right)$ groups by Frost et al. (2006), is, on the contrary, uncertain; indeed, As was found to be below the detection limit in the sample studied from the Tripi mine. Moreover, Plášil et al. (2014) interpreted some bands observed at 722,812 and $859 \mathrm{~cm}^{-1}$ in the Raman spectrum of hydroniumjarosite as due to $\delta(\mathrm{OH})$ modes, in keeping with the chemistry of the kintoreite studied.

In the region between 1500 and $1700 \mathrm{~cm}^{-1}$, a weak band at $1603 \mathrm{~cm}^{-1}$ was observed (Fig. 2b); Frost et al. (2006) reported a Raman band at $1595.6 \mathrm{~cm}^{-1}$, attributed to the occurrence of $\mathrm{H}_{2} \mathrm{O}$ groups. Indeed, this could be interpreted as due to the $\mathrm{O}-\mathrm{H}-\mathrm{O}$ bending of $\mathrm{H}_{2} \mathrm{O}$ groups. The Raman spectrum of the studied material in the region between 2800 and $3400 \mathrm{~cm}^{-1}$ is different from that reported by Frost et al. (2006). In fact they observed a broad band related to the convolution of three components at $2967.8,3224.6$, and $3391.1 \mathrm{~cm}^{-1}$. On the contrary, in kintoreite from the Tripi mine (Fig. 2c). four weak bands were observed, three of them forming a relatively broad band between 2800 and $3000 \mathrm{~cm}^{-1}$, and the fourth one occurring as a relatively sharp band at $3060 \mathrm{~cm}^{-1}$.

\section{Crystal-chemistry of kintoreite from the Tripi mine}

Kintoreite is isotypic with other alunite-supergroup minerals, a series of phases having the general formula $\mathrm{DG}_{3}\left(\mathrm{TO}_{4}\right)_{2}(\mathrm{OH}$, $\left.\mathrm{H}_{2} \mathrm{O}\right)_{6}$ (Stoffregen et al., 2000); in the sample studied, $\mathrm{D}=\mathrm{Pb}^{2+}$, $\mathrm{G}=(\mathrm{Fe}, \mathrm{Al})^{3+}$ and $\mathrm{T}=\left(\mathrm{P}^{5+}\right.$ and $\left.\mathrm{S}^{6+}\right)$. The crystal structure is characterised by sheets of corner-sharing $(\mathrm{Fe}, \mathrm{Al}) \phi_{6}\left[\phi=\mathrm{O}^{2-}\right.$ and $\left.(\mathrm{OH})^{-}\right]$ octahedra parallel to (0001) and decorated on both sides by $(\mathrm{P}, \mathrm{S}) \phi_{4}$ tetrahedra. Lead atoms are hosted within cavities occurring between the octahedral sheets (Fig. 3).

\section{Cation sites}

Lead is hosted in a distorted icosahedron and is displaced from the origin, being distributed in a ring-like structure in the (0001) plane at the $18 h$ position. In hinsdalite, $\mathrm{PbAl}_{3}\left(\mathrm{PO}_{4}\right)\left(\mathrm{SO}_{4}\right)(\mathrm{OH})_{6}$, and plumbogummite, $\mathrm{Pb}$ occurs at the $18 f$ position (Kolitsch et al., 1999), as in the refinement of kintoreite reported by Grey et al. (2009). On the contrary, Kharisun et al. (1997) proposed a model where $\mathrm{Pb}$ is located on a $36 i$ position. Moreover, this element is located at the origin in corkite, $\mathrm{PbFe}_{3}\left(\mathrm{PO}_{4}\right)\left(\mathrm{SO}_{4}\right)(\mathrm{OH})_{6}$, and osarizawaite, $\mathrm{Pb}\left(\mathrm{Al}_{2} \mathrm{Cu}^{2+}\right)\left(\mathrm{SO}_{4}\right)_{2}(\mathrm{OH})_{6}$, but with anomalously large displacement parameters (Giuseppetti and Tadini, 1980, 1987). The distorted twelve-fold coordination shown by $\mathrm{Pb}$ in kintoreite from the Tripi mine is characterised by six short bonds ( $\mathrm{Pb}-\phi$ distance shorter than $2.80 \AA$ ) and six longer ones. This distortion is probably due to the activity of the $6 s^{2}$ lone-pair of $\mathrm{Pb}^{2+}$. The average $\langle\mathrm{Pb}-\phi\rangle$ distance is $2.833 \AA$, to be compared with $2.842 \AA$ and $2.846 \AA$ for kintoreite studied by Kharisun et al. (1997) and Grey et al. (2009), respectively. These values can be compared with those observed in other Pb-bearing alunitesupergroup minerals, e.g. $2.79 \AA$ in hinsdalite and plumbogummite (Kolitsch et al., 1999), $2.823 \AA$ in corkite (Giuseppetti and Tadini, 1987) and $2.858 \AA$ in beudantite (Szymański, 1988). In these phases, the $<\mathrm{Pb}-\mathrm{O}(2)>$ distances are longer than the $<\mathrm{Pb}-$ $\mathrm{O}(3)>$, e.g. 2.87 vs. $2.80 \AA$ in beudantite (Szymański, 1988), 2.92 vs. $2.73 \AA$ in corkite (Giuseppetti and Tadini, 1987) and 2.82 vs. $2.78 \AA$ in gallobeudantite (Jambor et al., 1996). In kintoreite from the Tripi mine, these values are 2.90 and $2.77 \AA$, respectively, to be compared with those given by Kharisun et al. (1997) and Grey et al. (2009), i.e. 2.92 vs. $2.79 \AA$ and 2.92 vs. $2.77 \AA$, respectively. The bond-valence sum at the $\mathrm{Pb}$ site is 2.09 valence units (vu), in agreement with the theoretical value. 

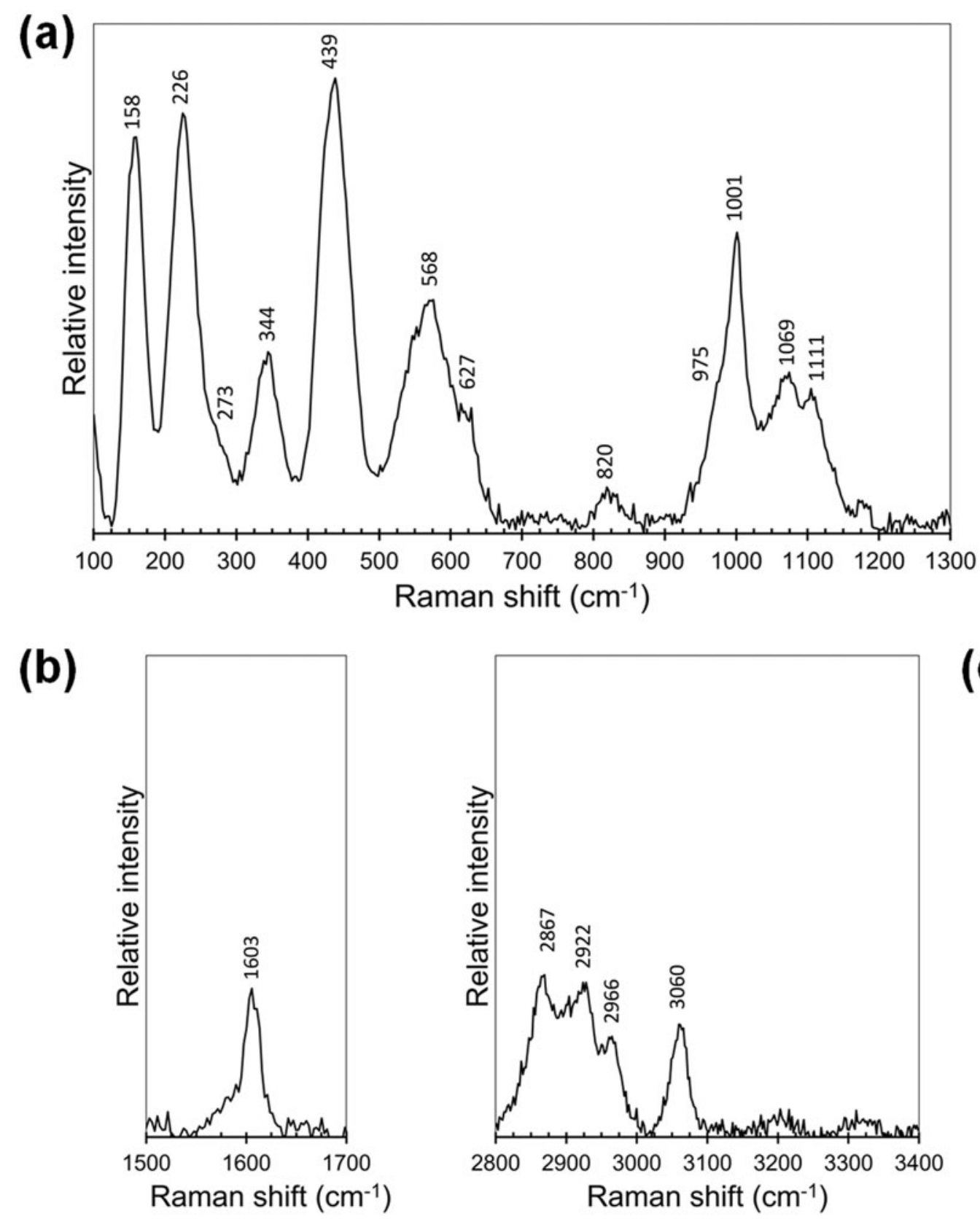

(c)

Fig. 2. Raman spectrum of kintoreite from the Tripi mine in the region (a) between 100 and $1300 \mathrm{~cm}^{-1} ;(\mathrm{b}) 1500-1700 \mathrm{~cm}^{-1}$; and (c) $2800-3400 \mathrm{~cm}^{-1}$.

Iron, replaced partially by $\mathrm{Al}$ and a minor vacancy, is the main $\mathrm{G}$ constituent and is hosted in a quite regular octahedron, formed by four equatorial $\mathrm{O}(3)$ sites and two apical $\mathrm{O}(2)$ sites. Average $\langle\mathrm{G}-\phi\rangle$ distance is $1.972 \AA$, shorter than those reported by Kharisun et al. (1997) and Grey et al. (2009), i.e. 2.011 $\AA$ in both structural models, owing to the extensive Al-to-Fe ${ }^{3+}$ replacement. Using the ionic radii proposed by Shannon (1976), the observed average bond distance would correspond to the Fe site occupancy $\left(\mathrm{Fe}_{0.70} \mathrm{Al}_{0.30}\right)$. This would correspond to the site population $\left(\mathrm{Fe}_{2.10} \mathrm{Al}_{0.90}\right)$, to be compared with $\left(\mathrm{Fe}_{1.89} \mathrm{Al}_{0.97} \square_{0.14}\right)$ and $\left(\mathrm{Fe}_{2.21} \mathrm{Al}_{0.53} \square_{0.26}\right)$ for the dark and bright domains, respectively. The discrepancy between electron microprobe data and calculated site population is probably due to the unaccounted occurrence of a vacancy. Refined site scattering at the $F e$ site is 63.2 electrons per formula unit (epfu), to be compared with 61.8 epfu calculated for the dark domain and 64.4 epfu for the brighter ones. The observed value is intermediate between these two values. The bond-valence sum at the $\mathrm{Fe}$ site was calculated on the basis of the site occupancy $\left(\mathrm{Fe}_{0.68} \mathrm{Al}_{0.32}\right)$ refined from single-crystal $\mathrm{X}$-ray diffraction data and it corresponds to $2.90 \mathrm{vu}$.

Phosphorus and minor $S$ are tetrahedrally coordinated, with an average $\langle\mathrm{T}-\phi\rangle$ distance of $1.526 \AA$. This distance is shorter than that reported by Kharisun et al. (1997), i.e. $1.563 \AA$, related to the partial substitution of $\mathrm{P}^{5+}$ by the larger $\mathrm{As}^{5+}$ cation. In 'pure' kintoreite studied by Grey et al. (2009), the corresponding distance is $1.537 \AA$, in agreement with the grand $\langle\mathrm{P}-\phi\rangle$ distance given by Huminicki and Hawthorne (2002). In the sample from the Tripi mine, $\mathrm{P}$ is replaced partially by $\mathrm{S}$. On the basis of the observed average distance, using the ideal distances reported by Huminicki and Hawthorne (2002) and Hawthorne et al. 


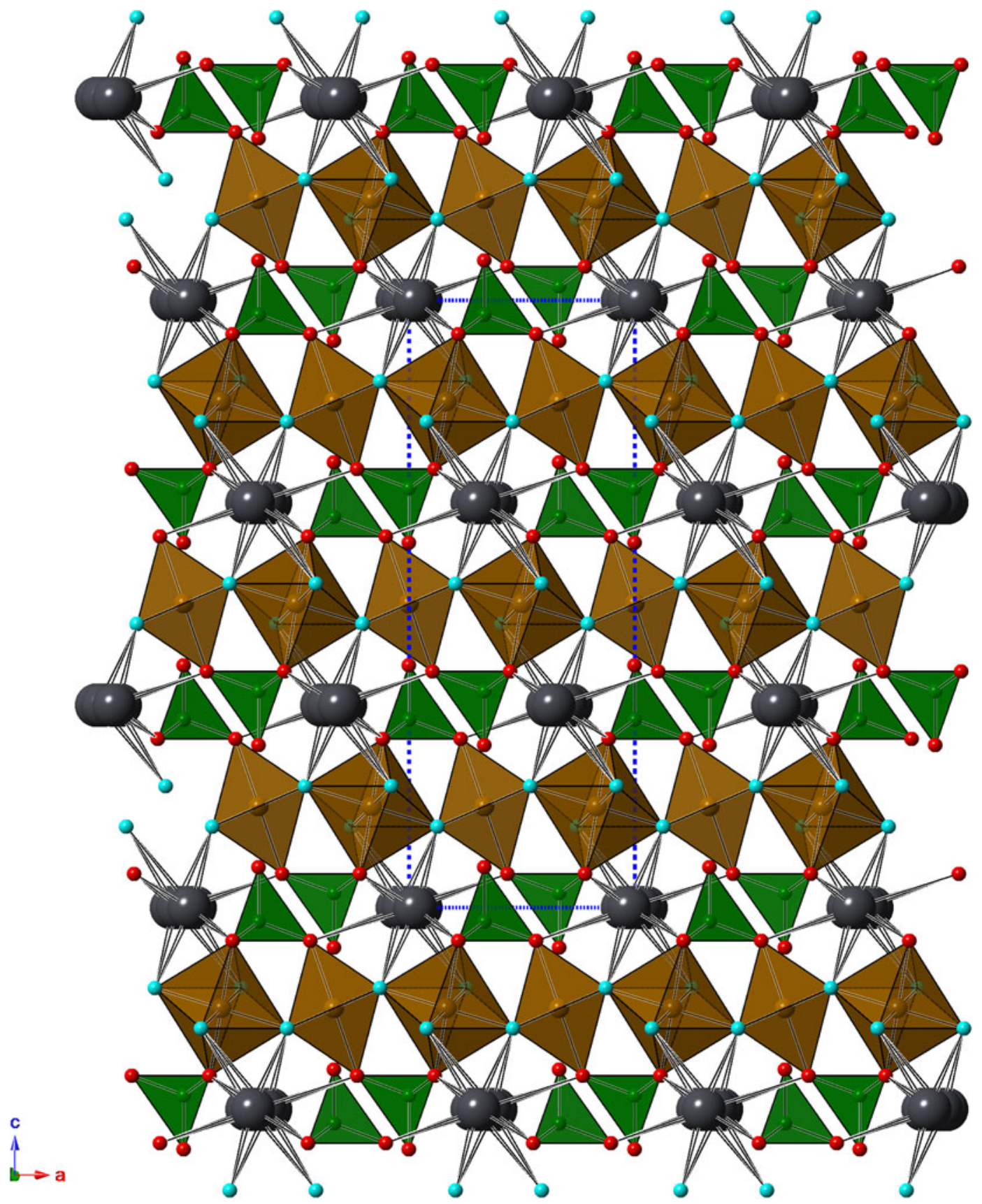

Fig. 3. Crystal structure of kintoreite as seen down b. Iron-centred and P-centred polyhedra are shown in brown and green, respectively. Large dark grey circles are $\mathrm{Pb}$ atoms, whereas $\mathrm{O}$ sites are shown as red circles. The $(\mathrm{OH})$-bearing $\mathrm{O}(3)$ site is shown as light blue circles. Hydrogen atoms are not shown. The unit-cell is shown as blue dotted lines.

(2000) for $\langle\mathrm{P}-\phi\rangle$ and $\langle\mathrm{S}-\phi\rangle$, respectively, the site occupancy $\left(\mathrm{P}_{0.83} \mathrm{~S}_{0.17}\right)$ for the $P$ site can be proposed. In comparison those observed in the dark and bright domains are $\left(\mathrm{P}_{0.785} \mathrm{~S}_{0.215}\right)$ and $\left(\mathrm{P}_{0.755} \mathrm{~S}_{0.245}\right)$, respectively. The bond-valence sum, calculated assuming the site occupancy $\left(\mathrm{P}_{0.78} \mathrm{~S}_{0.22}\right)$, is $5.15 \mathrm{vu}$, in accord with the partial replacement of $\mathrm{P}^{5+}$ by $\mathrm{S}^{6+}$. In kintoreite, $\mathrm{P}$ and $\mathrm{S}$ are disordered, as observed in other mixed $(\mathrm{P}, \mathrm{S})$ phases belonging to the alunite supergroup, e.g. woodhouseite, $\mathrm{CaAl}_{3}\left(\mathrm{PO}_{4}\right)\left(\mathrm{SO}_{4}\right)(\mathrm{OH})_{6}$ (Kato, 1977), svanbergite, $\mathrm{SrAl}_{3}\left(\mathrm{PO}_{4}\right)\left(\mathrm{SO}_{4}\right)(\mathrm{OH})_{6}$ (Kato and Miura, 1977) and hinsdalite (Kolitsch et al., 1999). The ordering of $\mathrm{P}$ and $\mathrm{S}$ in corkite reported by Giuseppetti and Tadini (1987) is considered questionable (e.g. Bayliss et al., 2010).

\section{Anion sites and $H$ bonds in kintoreite}

Three anion sites occur in the crystal structure of kintoreite, i.e. $\mathrm{O}(1), \mathrm{O}(2)$ and $\mathrm{O}(3)$.

$\mathrm{O}(1)$ is bonded to $(\mathrm{P}, \mathrm{S})$ only, with a relatively short distance of $1.510 \AA$. Its bond-valence sum indicates a significant underbonding, 1.34 vu. $\mathrm{O}(2)$ is corner-shared between one $(\mathrm{P}, \mathrm{S})$-centred tetrahedron and an $(\mathrm{Fe}, \mathrm{Al})$-centred octahedron. Moreover, it is 
bonded to disordered $\mathrm{Pb}$ atoms. Its bond-valence sum ranges between 1.81 and $2.02 \mathrm{vu}$, in relation to the different $\mathrm{Pb}$ ordered positions. $\mathrm{O}(3)$ is shared between two $(\mathrm{Fe}, \mathrm{Al})$-centred octahedra and one disordered $\mathrm{Pb}$ atom. Its bond-valence sum ranges between 1.10 and $1.26 \mathrm{vu}$. The difference-Fourier map revealed an $\mathrm{H}$ atom at $0.97(5) \AA$ from $\mathrm{O}(3)$ and forming an $\mathrm{O}(3)-\mathrm{H}(1) \cdots \mathrm{O}(1) \mathrm{H}$ bond with $\mathrm{O}(1) \cdots \mathrm{O}(3)$ distance of $2.814(9) \AA$ and an angle of $179(17)^{\circ}$. Using the relations proposed by Ferraris and Ivaldi (1988), a bond strength of 0.18 vu can be calculated for this $\mathrm{H}$ bond. In this way, the bond-valence sum at $\mathrm{O}(3)$, that acts as a donor, ranges between 0.92 and $1.08 \mathrm{vu}$, whereas $\mathrm{O}(1)$, acceptor of three $\mathrm{H}$ bonds, increases its bond-valence sum up to $1.88 \mathrm{vu}$. However, as stressed by Cooper and Hawthorne (2012), $O(1)$ should have a mixed occupancy $\left[\mathrm{O}_{0.5}(\mathrm{OH})_{0.5}\right]$ in alunite-supergroup minerals having the general formula $\mathrm{D}^{2+} \mathrm{G}_{3}^{3+}\left(\mathrm{T}^{5+} \mathrm{O}_{4}\right)\left(\mathrm{T}^{5+} \mathrm{O}_{3} \mathrm{OH}\right)(\mathrm{OH})_{6}$, as in kintoreite (e.g. Grey et al., 2009). In agreement with Cooper and Hawthorne (2012), when $\mathrm{O}(1)$ is occupied by $\mathrm{O}^{2-}$, then it is the acceptor of $\mathrm{H}$ bonds from three symmetry-related $\mathrm{OH}$ groups hosted at $\mathrm{O}(3)$ and one weak $\mathrm{H}$ bond from an $\mathrm{OH}$ group hosted at opposing $\mathrm{O}(1)$ apices of a $\mathrm{T} \phi_{4}$ group; on the contrary, when $\mathrm{O}(1)$ is an $\mathrm{OH}$ group, then it cannot be acceptor of the three $\mathrm{H}$ bonds from $\mathrm{O}(3)$. In this case, following Cooper and Hawthorne (2012), it can be hypothesised that the $\mathrm{H}$ bonds are accepted by the $\mathrm{O}^{2-}$ atoms hosted at the $\mathrm{O}(2)$ sites, located at the base of the $\mathrm{T} \phi_{4}$ groups. The $\mathrm{H}$ atom bonded to $\mathrm{O}(1)$ was not located. The $\mathrm{O}(1) \cdots \mathrm{O}(1)$ distance is $\sim 3.38 \AA$, corresponding to a very weak $\mathrm{H}$ bond, having a bond strength of $0.09 \mathrm{vu}$. Also the $\mathrm{O}(3) \cdots \mathrm{O}(2)$ distance is long, i.e. $\sim 3.38 \AA$. The $\mathrm{O}(3)-\mathrm{H}(1) \cdots \mathrm{O}(2)$ angle, $\approx 121^{\circ}$, is very small, close to the lower limit of observed $\mathrm{O}-\mathrm{H} \cdots \mathrm{O}$ bonds and indicative of a very weak bond (Brown, 1976). These values can be compared with those given by Cooper and Hawthorne (2012) for philipsbornitehidalgoite, i.e. $\mathrm{O}(3) \cdots \mathrm{O}(2)=3.54 \AA$ and $\mathrm{O}(3)-\mathrm{H}(1) \cdots \mathrm{O}(2)=116^{\circ}$. The proposed H-bonding is shown in Fig. 4.

Micro-Raman spectroscopy reveals the occurrence of possible $\mathrm{H}-\mathrm{O}-\mathrm{H}$ bending modes in kintoreite, thus supporting the presence of $\mathrm{H}_{2} \mathrm{O}$ groups. Although $\mathrm{H}_{2} \mathrm{O}$ groups may be the result of the protonation of $(\mathrm{OH})^{-}$groups, as suggested by Szymański (1985), a more reliable hypothesis is that the occurrence of $\mathrm{H}_{2} \mathrm{O}$ is related to the presence of octahedral vacancies. Their occurrence has been suggested by previous investigators (e.g. Jambor and Dutrizac, 1983; Szymański, 1985) and they seem to be coupled with the protonation of equatorial $\mathrm{H}_{2} \mathrm{O}$ groups of octahedral sites, as described by Nielsen et al. (2007).

\section{Variation of unit-cell parameters}

Unit-cell parameters of alunite-supergroup minerals are sensitive to the complex homo- and heterovalent substitutions accepted by their crystal structure.

Pring et al. (1995) reported the following unit-cell parameters for type kintoreite: $a=7.325(1), c=16.900(3) \AA$ and $V=785.3(5) \AA^{3}$. This type material showed significant $A$ s and $S$ replacing $P$, along with minor $\mathrm{CO}_{3}$ groups. The compositionally similar sample studied by Kharisun et al. (1997) gave similar values: $a=7.3310$ (7), $c=16.885(2) \AA$ and $V=785.9(2) \AA^{3}$. Pure kintoreite (i.e. with negligible substitution of $\mathrm{P}$ by $\mathrm{S}$ and no other octahedral cations than $\mathrm{Fe}^{3+}$ ) has unit-cell parameters $a=7.2963(5), c=$ 16.8491(5) $\AA$ and $V=776.8 \AA^{3}$ (Grey et al., 2009). Other unit-cell parameters for kintoreite available in literature are those reported by Pauliš et al. (2012) for a sample with minor $\mathrm{Cu}^{2+}$ as octahedral cation and As replacing $\mathrm{P}[a=7.290(1), c=16.8654(1) \AA$ and $V=$ $\left.776.2(2) \AA^{3}\right]$, and by Števko et al. (2016), who reported the

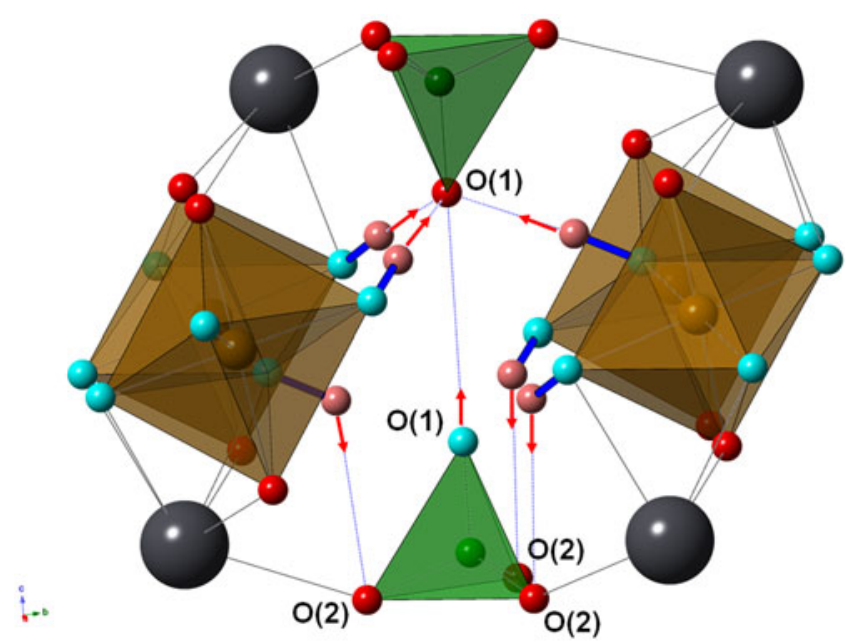

Fig. 4. Fragment of the crystal structure of kintoreite showing the $\mathrm{H}$ bonding involving $\mathrm{O}(3)$ (light blue) and $\mathrm{O}(1)$ (light blue and red if donor or acceptor of $\mathrm{H}$ bonds, respectively) sites. Red arrows indicate the $\mathrm{H}$ bonds. Same symbols as in Fig. 3. Hydrogen atoms are shown as pink circles.

unit-cell parameters for a specimen showing a partial replacement of $\mathrm{Fe}^{3+}$ by $\mathrm{Al}(0.34 \mathrm{apfu}), \mathrm{Cu}^{2+}(0.14 \mathrm{apfu})$, and minor vacancy (0.04 apfu), with $\mathrm{P}$ replaced by Si $(0.16 \mathrm{apfu}), \mathrm{S}(0.02 \mathrm{apfu})$ and As $(0.01) \quad\left[a=7.286(8), c=16.883(5) \AA\right.$ and $\left.V=776(1) \AA^{3}\right]$. Hatert and Lefèvre (2004) reported the unit-cell parameters for kintoreite from the Stavelot massif, Belgium, showing a very long $c$ parameter, i.e. $17.08(2) \AA$. No quantitative chemical data are available.

The sample from the Tripi mine has an exceptionally small unit-cell volume, i.e. 759.8(3) $\AA^{3}$, with $a=7.2191(10)$ and $c=16.834(3) \AA$. Assuming the unit-cell parameters of the specimen studied by Grey et al. (2009) as a reference for ideal kintoreite, the specimen from the Tripi mine has $\Delta a=-1.1 \%, \Delta c=-0.1 \%$ and $\Delta V=-2.2 \%$. As discussed by other authors (e.g. Stoffregen et al., 2000), the $a$ unit-cell parameter is affected mainly by the $\mathrm{Fe}^{3+}-\mathrm{Al}$ substitution, whereas variations of the unit-cell parameter $c$ are largely related to substitution at the twelve-fold coordinated site. Consequently, the contraction of the Tripi mine sample is probably due to the high $\mathrm{Al}$ content of the material studied, supporting the existence of a substitutional series with the Al-isotype plumbogummite.

\section{Conclusions}

Kintoreite from the Tripi mine represents the first wellcharacterised Italian occurrence of this uncommon member of the alunite supergroup. Using a multi-analytical approach (electron microprobe analysis, single-crystal X-ray diffraction, and micro-Raman spectroscopy), the crystal chemical features of this mineral species were determined, detailing the $\mathrm{H}$-bond system and suggesting the occurrence of $\mathrm{H}_{2} \mathrm{O}$ groups, probably due to the presence of an octahedral vacancy. In this way, the plasticity of the alunite structure to accommodate several substitutions is further confirmed. This is particularly important as kintoreite is able to host PTE such as $\mathrm{Pb}$. Indeed, in the Ali area, high $\mathrm{Pb}$ content of geogenic origin in soils has been reported by Cosenza et al. (2015).

Notwithstanding the current lack of mineralogical studies aiming at constraining the mineralogy of secondary assemblages from 
the Peloritani Mountains, it is very likely that alunite-supergroup minerals may play a central role in determining the fate of PTE in this former mining district. The finding and characterisation of kintoreite could represent a first step in assessing the environmental role of these phases in this sector of northeastern Sicily.

Acknowledgements. K. Gariboldi is acknowledged for her assistance during the SEM study. The University Centrum for Applied Geosciences (UCAG) is thanked for the access to the 'Eugen F. Stumpfl' electron microprobe laboratory. This research was supported financially by the Ministero dell'Istruzione, Università e Ricerca through the project PRIN 2017 'TEOREM - deciphering geological processes using Terrestrial and Extraterrestrial ORE Minerals', prot. 2017AK8C32. Comments of Peter Leverett and two anonymous reviewers helped us in improving the paper.

The Authors are delighted to contribute to the thematic issue honouring Prof. Peter A. Williams. We believe that the complex crystal chemistry of kintoreite and its environmental significance reflects well the main interest that Pete has had during his scientific activity.

Supplementary material. To view supplementary material for this article, please visit https://doi.org/10.1180/mgm.2021.85

\section{References}

Albertini C. (2014) Minerali del Vergante e della Valle dell'Agogna. In: Miniere e minerali del Vergante e Val d'Agogna (C. Manni, editor). Italgrafica, Novara, Italy, $512 \mathrm{pp}$.

Baldanza B. (1950) Ricerche sulle mineralizzazioni dei Peloritani. I. Il giacimento di Contrada Tripi di Alì (Messina). Periodico di Mineralogia, 19, 1-40.

Bayliss P., Kolitsch U., Nickel E.H., and Pring A. (2010) Alunite supergroup: recommended nomenclature. Mineralogical Magazine, 74, 919-927.

Brown I.D. (1976) On the geometry of $\mathrm{O}-\mathrm{H} \cdots \mathrm{O}$ hydrogen bonds. Acta Crystallographica, A32, 24-31.

Bruker AXS Inc. (2016) APEX3. Bruker Advanced X-ray Solutions, Madison, Wisconsin, USA.

Carbone S., Messina A. and Lentini F. (2007) Note illustrative della Carta Geologica d'Italia alla scala 1:50.000. Foglio 601. Messina-Reggio di Calabria. Servizio Geologico d'Italia, Rome.

Cooper M.A. and Hawthorne F.C. (2012) Refinement of the crystal structure of zoned philipsbornite-hidalgoite from the Tsumeb mine, Namibia, and hydrogen bonding in the $\mathrm{D}^{2+} \mathrm{G}^{3+}\left(\mathrm{T}^{5+} \mathrm{O}_{4}\right)\left(\mathrm{TO}_{3} \mathrm{OH}\right)(\mathrm{OH})_{6}$ alunite structures. Mineralogical Magazine, 76, 839-849.

Cosenza A., Lima A., Ayuso R.A., Foley N.K., Albanese S., Messina A. and De Vivo B. (2015) Soil geochemical survey of abandoned mining sites in the Eastern-Central Peloritani Mountains, Sicily, Italy. Geochemistry: Exploration, Environment, Analysis, 15, 361-372.

De Vivo B., Lima A., Catalano G. and Chersicla A. (1993) Detailed geochemical survey in the Peloritani Arc (northeastern Sicily, Italy): Evidence of gold anomalies. Journal of Geochemical Exploration, 46, 309-324.

Ferla P. and Meli C. (2007) Petrogenesis of tourmaline rocks associated with Fe-carbonate-graphite metapelite, metabasite and strata-bound polymetallic sulphide mineralization, Peloritani Mountains, Sicily, Southern Italy. Lithos, 99, 266-288.

Ferla P. and Omenetto P. (2000) Metallogenetic evolution of Peloritani Mountains (NE Sicily): a summary. Memorie della Società Geologica Italiana, 55, 293-297.

Ferraris G. and Ivaldi G. (1988) Bond valence vs bond length in O $\cdots$ O hydrogen bonds. Acta Crystallographica, B44, 341-344.

Frost R.L., Weier M.L., Martens W. and Mills S. (2006) ThermoRaman spectroscopic study of kintoreite. Spectrochimica Acta Part A, 63, 282-288.

Gagné O.C. and Hawthorne F.C. (2015) Comprehensive derivation of bondvalence parameters for ion pairs involving oxygen. Acta Crystallographica, B71, 562-578.

Giuseppetti G., and Tadini C. (1980) The crystal structure of osarizawaite. Neues Jahrbuch für Mineralogie, Monatshefte, 1980, 401-407.
Giuseppetti G. and Tadini C. (1987) Corkite, $\mathrm{PbFe}_{3}\left(\mathrm{SO}_{4}\right)\left(\mathrm{PO}_{4}\right)(\mathrm{OH})_{6}$, its crystal structure and ordered arrangement of the tetrahedral cations. Neues Jahrbuch für Mineralogie, Monatshefte, 1987, 71-81.

Grey I.E., Mumme W.G., Mills S.J., Birch W.D. and Wilson N.C. (2009) The crystal chemical role of $\mathrm{Zn}$ in alunite-type minerals: Structure refinements for kintoreite and zincian kintoreite. American Mineralogist, 94, 676-683.

Guastoni A., Gentile P. and Soldani V. (2018) Kintoreite di Chiotta Strivera, valle di Nac, Coiromonte (VCO). Novità di mineralogia sistematica italiana. Rivista Mineralogica Italiana, 42, 210-212.

Hatert F. and Lefèvre P. (2004) Carminite et kintoreite de Hourt, Massif de Stavelot, Belgique. Bulletin de la Société Royale des Sciences de Liège, 73, $35-41$.

Hawthorne F.C., Krivovichev S.V. and Burns P.C. (2000) The crystal chemistry of sulfate minerals. Pp. 1-112 in: Sulfate Minerals: Crystallography, Geochemistry, and Environmental Significance (C.N. Alpers, J.L. Jambor and D.K. Nordstrom, editors). Reviews in Mineralogy and Geochemistry, Vol. 40. Mineralogical Society of America and the Geochemical Society, Washington DC.

Huminicki D.M.C. and Hawthorne F.C. (2002) The crystal chemistry of the phosphate minerals. Pp. 123-253 in: Phosphates (M.L. Kohn, J. Rakovan, and J.M. Hughes, editors). Reviews in Mineralogy and Geochemistry, Vol. 48. Mineralogical Society of America and the Geochemical Society, Washington DC.

Ferla P. (1982/1983) Inquadramento geologico-petrografico delle mineralizzazioni metallifere nei Monti Peloritani (Sicilia). Rendiconti della Società Italiana di Mineralogia e Petrologia, 38, 1075-1091.

Jambor J.L. and Dutrizac J.E. (1983) Beaverite-plumbojarosite solid solutions. The Canadian Mineralogist, 21, 101-113.

Jambor J.L., Owens D.R., Grice J.D. and Feinglos M.N. (1996) Gallobeudantite, $\mathrm{PbGa}_{3}\left[\left(\mathrm{AsO}_{4}\right),\left(\mathrm{SO}_{4}\right)\right]_{2}(\mathrm{OH})_{6}$, a new mineral species from Tsumeb, Namibia, and associated new gallium analogues of the alunite-jarosite family. The Canadian Mineralogist, 34, 1305-1315.

Kato T. (1977) Further refinement of the woodhouseite structure. Neues Jahrbuch für Mineralogie, Monatshefte, 1977, 54-58.

Kato T. and Miura Y. (1977) The crystal structures of jarosite and svanbergite. Mineralogical Journal, 8, 419-430.

Kharisun, Taylor M.R. and Bevan D.J.M. (1997) The crystal structure of kintoreite, $\mathrm{PbFe}_{3}\left(\mathrm{PO}_{4}\right)_{2}\left(\mathrm{OH}, \mathrm{H}_{2} \mathrm{O}\right)_{6}$. Mineralogical Magazine, 61, 123-129.

Kolitsch U., Tiekink E.R.T., Slade P.G., Taylor M.R. and Pring A. (1999) Hinsdalite and plumbogummite, their atomic arrangements and disordered lead sites. European Journal of Mineralogy, 11, 513-520.

La Valle G. (1898) Su di alcuni nuovi minerali cobaltiferi e nichiliferi nella provincia di Messina. Atti della R. Accademia dei Lincei, Rendiconti, 7, 68-71.

La Valle G. (1899) I giacimenti metalliferi di Sicilia in provincia di Messina. Tipografia Fratelli Fugazotto, Messina, 83 pp.

Messina A., Somma R., Macaione E., Carbone G. and Careri G. (2004) Peloritani continental crust composition (Southern Italy): geological and petrochemical evidence. Bollettino della Società Geologica Italiana, 123, 405-441.

Nielsen U.G., Majzlan J., Phillips B., Ziliox M. and Grey, C.P. (2007) Characterization of defects and the local structure in natural and synthetic alunite $\left(\mathrm{K}, \mathrm{Na}, \mathrm{H}_{3} \mathrm{O}\right) \mathrm{Al}_{3}\left(\mathrm{SO}_{4}\right)_{2}(\mathrm{OH})_{6}$ by multi-nuclear solid-state NMR spectroscopy. American Mineralogist, 92, 587-597.

Pauliš P., Toegel V. and Jebavá I. (2012) Kintoreite from the uranium deposit Zálesí in the Rychlebské hory Mountains (Czech Republic). Bulletin Mineralogicko-Petrologického Oddělení Národního Muzea (Praha), 20, 223-225 [in Czech, with English abstract].

Plášil J., Škoda R., Fejfarová K., Čejka J., Kasatkin A.V., Dušek M., Talla D., Lapčák L., Machovič V. and Dini M. (2014) Hydroniumjarosite, $\left(\mathrm{H}_{3} \mathrm{O}\right)^{+} \mathrm{Fe}_{3}\left(\mathrm{SO}_{4}\right)_{2}(\mathrm{OH})_{6}$, from Cerros Pintados, Chile: Single-crystal X-ray diffraction and vibrational spectroscopic study. Mineralogical Magazine, 78, 535-547.

Pring A., Birch W.D., Dawe J., Taylor M., Deliens M. and Walenta K. (1995) Kintoreite, $\mathrm{PbFe}_{3}\left(\mathrm{PO}_{4}\right)_{2}\left(\mathrm{OH}, \mathrm{H}_{2} \mathrm{O}\right)_{6}$, a new mineral of the jarosite-alunite family, and lusungite discredited. Mineralogical Magazine, 59, 143-148. 
Saccà C., Saccà D., Nucera P. and Somma R. (2003) Gold-bearing polymetalliferous mineralization in the Central Peloritani Mts. (NE Sicily, Italy). Bollettino della Società Geologica Italiana, 122, 503-509.

Saccà C., Saccà D., Nucera P., De Fazio A. and D’Urso D. (2007) Geochemical and mineralogical features of the polymetallic deposit from Ali (NE Sicily, Italy). Atti dell'Accademia Peloritana dei Pericolanti, 85, 1-12.

Saccà C., Saccà D. and Nucera P. (2015) Le mineralizzazioni dei Monti Peloritani. Storia e attualità. Aracne Editrice, Roma, 300 p.

Schindler M. and Hochella M.F.Jr. (2017) Sequestration of Pb-Zn-Sb- and As-bearing incidental nanoparticles by mineral surface coatings and mineralized organic matter in soils. Environmental Science: Processes \& Impacts, 19, 1016-1027.

Seguenza G. (1856) Ricerche mineralogiche sui filoni metalliferi di Fiumedinisi e suoi dintorni in Sicilia. Stamperia Antonino D'Amico Arena, Messina, $70 \mathrm{p}$.

Shannon R.D. (1976) Revised effective ionic radii and systematic studies of interatomic distances in halides and chalcogenides. Acta Crystallographica, A32, 751-767.

Sheldrick G.M. (2015) Crystal structure refinement with SHELXL. Acta Crystallographica, C71, 3-8.

Števko M., Sejkora J. and Malíková R. (2016) New data on supergene minerals from the Rainer mining field, Lubietová-Podlipa deposit (Slovak Republic). Bulletin Mineralogicko-Petrologického Oddělení Národního Muzea (Praha), 24, 1-12 [in Czech, with English abstract].

Stoffregen R.E., Alpers C.N. and Jambor J.L. (2000) Alunite-jarosite crystallography, thermodynamics, and geochronology. Pp. 453-479 in: Sulfate Minerals: Crystallography, Geochemistry, and Environmental Significance (C.N. Alpers, J.L. Jambor and D.K. Nordstrom, editors). Reviews in Mineralogy and Geochemistry, Vol. 40. Mineralogical Society of America and the Geochemical Society, Washington DC.
Szymański J.T. (1985) The crystal structure of plumbojarosite $\mathrm{Pb}$ $\left[\mathrm{Fe}_{3}\left(\mathrm{SO}_{4}\right)_{2}(\mathrm{OH})_{6}\right]_{2}$. The Canadian Mineralogist, 23, 659-668.

Szymański J.T. (1988) The crystal structure of beudantite, $\mathrm{Pb}(\mathrm{Fe}, \mathrm{Al})_{3}[(\mathrm{As}, \mathrm{S})$ $\left.\mathrm{O}_{4}\right]_{2}(\mathrm{OH})_{6}$. The Canadian Mineralogist, 26, 923-932.

Traina E. (1905) Sull'anglesite dei giacimenti metalliferi della provincia di Messina. Atti della R. Accademia dei Lincei, Rendiconti, 14, 220-223.

Triscari M. (1985) A first occurrence of gersdorffite in the Peloritani Mts. (Sicily N.E.). Rendiconti della Società Italiana di Mineralogia e Petrologia, 40, 289-294.

Triscari M., and Saccà C. (1982) Scheelite at the S. Carlo Sb-Cu-Ag mine, Fiumedinisi, Messina, Italy. Mineralogica et Petrographica Acta, 26, 159-168.

Triscari M. and Saccà C. (1984) Contributo alla conoscenza dei minerali metalliferi dei Monti Peloritani (Sicilia N.E.) VI) La boulangerite. Rendiconti della Società Italiana di Mineralogia e Petrologia, 39, 145-154.

Vrtiška L., Malíková R. and Sejkora J. (2016) An interesting phosphate occurrence around Líštěnec near Votice (Czech Republic). Bulletin Mineralogicko-Petrologického Oddelení Národního Muzea (Praha), 24, 114-131 [in Czech, with English abstract].

Vrtiška L., Malíková R., Dolníček Z. and Sejkora J. (2019) Pyromorphite, kintoreite and cerussite from the historical $\mathrm{Ag}-\mathrm{Pb}-\mathrm{Zn}$ ore deposit Ratibořské Hory (Czech Republic). Bulletin Mineralogicko-Petrologického Odděleni Národního Muzea (Praha), 27, 394-409 [in Czech, with English abstract].

Vrtiška L., Sejkora J., Dolníček Z. and Malíková R. (2021) Sn-rich phosphates kintoreite and plumbogummite from Ratibořské Hory $\mathrm{Ag}-\mathrm{Pb}-\mathrm{Zn}$ deposit, Czech Republic. Acta Mineralogica-Petrographica, Abstract Series, 11, 52.

Wilson, A.J.C. (1992) International Tables for Crystallography. Volume C: Mathematical, Physical and Chemical Tables. Kluwer Academic Publishers, Dordrecht, The Netherlands.

Wojdyr, M. (2010) Fityk: a general-purpose peak fitting program. Journal of Applied Crystallography, 43, 1126-1128. 